\title{
Enabling Electrocatalytic Fischer-Tropsch Synthesis from Carbon Dioxide Over Copper-based Electrodes
}

\author{
Hirokazu Shibata • Jacob A. Moulijn • \\ Guido Mul
}

Received: 15 January 2008/Accepted: 11 April 2008/Published online: 1 May 2008

(C) The Author(s) 2008

\begin{abstract}
We report on the discovery that paraffins and olefins up to $\mathrm{C}_{6}$ hydrocarbons can be obtained in $\mathrm{CO}_{2}$ electroreduction at room temperature and atmospheric pressure by application of a commercially available $\mathrm{Cu}$-electrode (Eurofysica), provided pretreatment by electropolishing is avoided. The product distribution follows the Schultz-Flory distribution and, depending on the applied potential, the chain growth probability $(\alpha)$ ranges from 0.23 to 0.31 , values lower than those obtained in Fischer-Tropsch synthesis over heterogeneous Co- or Fe-based catalysts.
\end{abstract}

Keywords $\mathrm{CO}_{2} \cdot \mathrm{Cu}$-electrodes $\cdot$ Fischer-Tropsch · Electrocatalysis

\section{Introduction}

For the conversion of renewable energy into a transportation fuel, many research groups have focused on the production of hydrogen [1]. Besides electrolysis, photocatalytic splitting of water into hydrogen and oxygen has been shown to be feasible [2], even with visible photons [3]. Hydrogen is, however, not a very convenient fuel, with respect to distribution and storage. Besides production of hydrogen, photocatalytic [4] or electrocatalytic conversion of $\mathrm{CO}_{2}$ with $\mathrm{H}_{2} \mathrm{O}$ is an option $[5,6]$, yielding fuel-like hydrocarbons which can be exploited in the current

H. Shibata · J. A. Moulijn · G. Mul (ه)

Catalysis Engineering, DelftChemTech, Delft University of

Technology, Julianalaan 136, 2628 BL Delft, The Netherlands

e-mail: g.mul@tudelft.nl infrastructure. Direct electrochemical reduction of $\mathrm{CO}_{2}$ in aqueous solutions has been studied intensively over copper-electrodes, and various reviews on this topic have appeared in the open literature. The product distribution of electro-catalytic $\mathrm{CO}_{2}$ reduction over $\mathrm{Cu}$ typically consists of carbon monoxide $(\mathrm{CO})$, methane $\left(\mathrm{CH}_{4}\right)$, ethene $\left(\mathrm{C}_{2} \mathrm{H}_{4}\right)$, ethanol $\left(\mathrm{C}_{2} \mathrm{H}_{5} \mathrm{OH}\right)$ and formic acid $(\mathrm{HCOOH})$ [7-9]. $\mathrm{Cu}$-based electrodes are quite unique in activating $\mathrm{CO}_{2}$, although the Faradaic efficiency is still small: the result of $\mathrm{H}_{2} \mathrm{O}$ dissociation to $\mathrm{H}_{2}[10,11]$. Intensive studies have been conducted to reveal the reaction mechanism of $\mathrm{Cu}$ catalyzed $\mathrm{CO}_{2}$ electroreduction, in which a Fischer-Tropsch mechanism, i.e. chain propagation, was proposed as one of the pathways [12, 13]. The group of Hori [14] applied several pre-treatment procedures to alter the surface roughness of $\mathrm{Cu}$ electrodes, and concluded that $\mathrm{C}_{2} \mathrm{H}_{6}$, a typical product of catalytic Fischer-Tropsch synthesis, was only observed if electro-polishing in acid, typically applied in other studies on $\mathrm{CO}_{2}$ reduction over $\mathrm{Cu}$ electrodes, was not conducted. Longer chain hydrocarbons were, however, not reported by the group of Hori for copper electrodes $[15,16]$. In the present paper a systematic study of the effect of the electrode pretreatment procedure on the performance is presented, specifically targeting the formation of higher hydrocarbons $\left(\mathrm{C}_{3}^{+}\right)$. The result is the exciting discovery that certain $\mathrm{Cu}$-electrodes produce products in $\mathrm{CO}_{2}$ electroreduction with a distribution as typically obtained in the Fischer-Tropsch reaction of syn-gas over heterogeneous Co- or Fe-based catalysts [17]. This is an important scientific discovery, since this is the first tangible evidence that chain propagation occurs during $\mathrm{CO}_{2}$ electroreduction over $\mathrm{Cu}$-electrodes. Furthermore, this work shows that besides on Pt/C-based electrodes [6], a gas to liquid process starting directly from $\mathrm{CO}_{2}$ is potentially also feasible over $\mathrm{Cu}$-electrodes. 


\section{Experimental}

Two commercial $\mathrm{Cu}$ foils (Eurofysica $\mathrm{Cu}$ foil: $99.9+\%$, $0.95 \mathrm{~mm}$ thick, and Alfa Aesar $\mathrm{Cu}$ foil, Puratronic ${ }^{\circledR}$, 99.9999\% (metals basis), $0.25 \mathrm{~mm}$ thick) were subsequently polished with 400 and 600 mesh emery papers (3 M 734) for $1 \mathrm{~min}$, and washed with acetone, ethanol, and distilled water. This was followed by ultra-sonication in distilled water for $10 \mathrm{~min}$. The pre-treated $\mathrm{Cu}$-foils were used as electrodes, either with, or without electropolishing in phosphoric acid solution $\left(\mathrm{H}_{3} \mathrm{PO}_{4}\right.$, Aldrich 85 wt.\% in water). During the electropolishing procedure, pre-treated $\mathrm{Cu}$-foils were applied as anode, and another $\mathrm{Cu}$ foil was used as cathode in one compartment. An absolute potential of $2.3 \mathrm{~V}$ was applied between the two $\mathrm{Cu}$ electrodes for $1 \mathrm{~min}$ [18].

Electrocatalytic conversion of $\mathrm{CO}_{2}$ was carried out in a three-electrode electrochemical cell at ambient temperature and pressure, shown in Fig. 1. A potentiostat, HSV-100 (Hokuto Denko) was used to induce electrocatalytic reduction by applying adequate potential differences over the electrodes. A platinum electrode (Pt, Hokuto Denko, $10 \times 20 \times 0.1 \mathrm{~mm}^{3}$ ) was employed as a counter-, and a silver/silver chloride couple $(\mathrm{Ag} / \mathrm{AgCl}$, Hokuto Denko, HS205-C) as a reference electrode. The counter electrode was placed in the same compartment as the $\mathrm{Cu}$-electrode $\left(10 \mathrm{~cm}^{2}\right)$. The reference electrode was located in another compartment and a connection to the electrochemical cell was established via a capillary and a salt bridge filled with $\mathrm{KCl} /$ agar. $\mathrm{A} \mathrm{CO}_{2}$-saturated $0.1 \mathrm{M}$ potassium bicarbonate $\left(\mathrm{KHCO}_{3}\right.$, Sigma Aldrich $\left.\geq 99.5 \%\right)$ aqueous solution was used as electrolyte. Prior to the electrocatalytic reduction, $\mathrm{CO}_{2}$ was bubbled through for $1 \mathrm{~h}$ to make the solution $\mathrm{CO}_{2}$ saturated. After saturation, the $\mathrm{pH}$ of the solution was 6.7. The $\mathrm{CO}_{2}$ feed and exit lines were closed off, and the reactor operated in batch mode.

Prior to the electrocatalytic experiments at fixed potential, a cathodic sweep analysis was conducted from the equilibrium electrode potential of the $\mathrm{Cu}$ electrode in the solution $(-0.050 \mathrm{~V}$ vs. $\mathrm{Ag} / \mathrm{AgCl})$ to negative electric potential $(-2.0 \mathrm{~V}$ vs. $\mathrm{Ag} / \mathrm{AgCl})$ with $1 \mathrm{mV} / \mathrm{s}$. A slow scan rate was applied to obtain a steady state polarization curve. The starting potential was restricted to the equilibrium potential to avoid the dissolution of $\mathrm{Cu}$ ions, which may introduce complications to the analysis, e.g. by re-deposition of $\mathrm{Cu}$ ions.

Gas phase hydrocarbons produced by the electrochemical reduction of $\mathrm{CO}_{2}$ at fixed potential were analyzed using a gas chromatograph (GC) equipped with an FID detector (carrier gas: Ar, column: Chrompack Poraplot Q, $50 \mathrm{~m} \times 0.53 \mathrm{~mm})$. Scotty ${ }^{\circledR}$ Scott calibration mixtures (15-20 ppm C1-C4 Hydrocarbons balanced in $\mathrm{N}_{2}$ (UN1956 Class 2-PKG200)), and Scott Speciality Gases

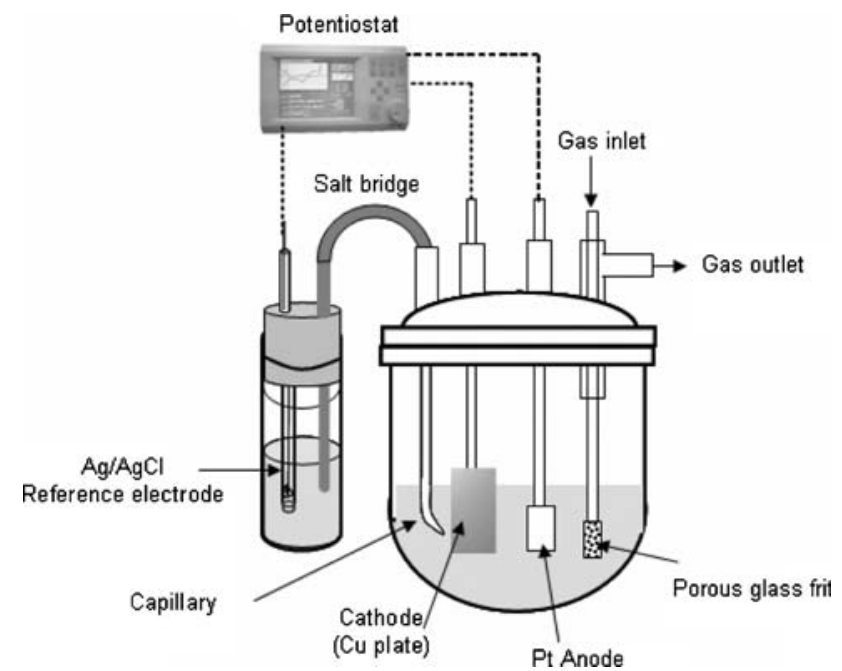

Fig. 1 Schematic overview of the electrocatalytic reactor used in the present study

mixture C1-C5 Hydrocarbons balanced in $\mathrm{N}_{2}$ (PO Nr. 45319472) were used as calibration gases for hydrocarbons. A volume of $0.5 \mathrm{ml}$ was extracted from the gas volume above the liquid and directly injected on the column for GC analysis. The liquid phase was analyzed for alcohols by a GC equipped with an FID detector (carrier gas: He, column: CP Wax $52 \mathrm{CB}, 50 \mathrm{~m} \times 0.32 \mathrm{~mm}$ ), but these were formed in quantities below the detection, if any. Production of $\mathrm{CO}$ was below the detection limit of the TCD applied in the GC analysis (Molecular Sieve $5 \AA$ ). Hydrogen was the co-product accounting for the observed Faradaic hydrocarbon efficiency.

The crystal morphology of the electrodes was analyzed by X-ray diffraction (XRD) and elemental analysis was conducted by X-ray Fluorescence Analysis (XRF). XRD measurements of the electrodes were performed using a $\theta-2$ $\theta$ diffractometer with an incident beam monochromator and a position sensitive detector $(\mathrm{Cu} \mathrm{K} \alpha 1$ radiation), set to an angular range of $30-100^{\circ} 2 \theta$. XRF measurements were performed on a Panalytical PW2400 wavelength dispersive XRF-spectrometer. The X-ray tube has a Rhodium anode and was operating at $2,400 \mathrm{~W}$.

\section{Results and Discussion}

The change in current density as a function of cathode potential for the Eurofysica Cu-foil (99.9+\%), used without electro-polishing, is shown in Fig. 2. The cathodic current density increases significantly at $-0.9 \mathrm{~V}$ vs. $\mathrm{Ag} / \mathrm{AgCl}$. This increase is due to a combination of water splitting into $\mathrm{H}_{2}$ and $\mathrm{O}_{2}$, and electrocatalytic $\mathrm{CO}_{2}$ conversions. It has been reported that $\mathrm{CO}$ and $\mathrm{HCOOH}$ are produced at moderate negative electric potential, and hydrocarbons, such as $\mathrm{CH}_{4}$ 


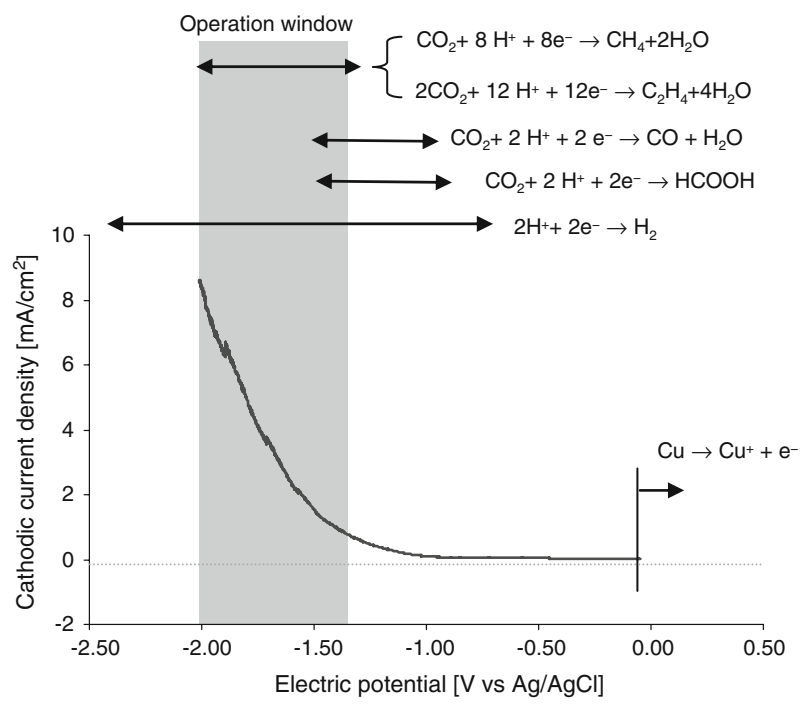

Fig. 2 A cathodic sweep analysis from the equilibrium electrode potential of the $\mathrm{Cu}$ electrode in the solution $(-0.050 \mathrm{~V}$ vs. $\mathrm{Ag} / \mathrm{AgCl})$ to a negative electric potential of $-2.0 \mathrm{~V}$ vs. $\mathrm{Ag} / \mathrm{AgCl}$ ). Scan rate: $1 \mathrm{mV} / \mathrm{s}$. Reactions and products indicated are based on literature data

and $\mathrm{C}_{2} \mathrm{H}_{4}$, are produced only at potentials lower than $-1.4 \mathrm{~V}$ vs. $\mathrm{Ag} / \mathrm{AgCl}$, as indicated in Fig. 2 [11]. In the present study we applied an operation window as indicated by the grey area in Fig. 2. In the following the gas phase products formed by reduction of $\mathrm{CO}_{2}$ in this potential range will be discussed in more detail.

Electro-catalytic $\mathrm{CO}_{2}$ reduction over unpolished Eurofysica $\mathrm{Cu}$-foil results in a unique selectivity. The gas chromatogram of electro-catalytic $\mathrm{CO}_{2}$ reduction at $-1.65 \mathrm{~V}$ vs. $\mathrm{Ag} / \mathrm{AgCl}$ (corresponding to galvanostatic operation at $2 \mathrm{~mA} / \mathrm{cm}^{2}$ ), obtained after 720 Coulomb has passed through the cell, is shown in Fig. 3a, and the weight fractions of the detected hydrocarbons are summarized in Fig. 3b. Not only $\mathrm{CH}_{4}$, and $\mathrm{C}_{2} \mathrm{H}_{4}$, which are typically reported in $\mathrm{CO}_{2}$ electrocatalytic reduction at $-1.65 \mathrm{~V}$ vs.
$\mathrm{Ag} / \mathrm{AgCl}$, but also longer chain paraffins and olefins up to $\mathrm{C}_{6}$ are formed. This is the first experimental evidence that chain propagation is possible in electrocatalytic reduction of $\mathrm{CO}_{2}$ over $\mathrm{Cu}$-electrodes at atmospheric temperature and pressure. It should be noted that a reference experiment in a $\mathrm{N}_{2}$ saturated $0.1 \mathrm{M} \mathrm{KHCO}_{3}$ solution did not result in hydrocarbon production. Therefore, neither bicarbonate $\left(\mathrm{HCO}_{3}^{-}\right)$nor impurities in the system contribute directly to the production of hydrocarbons.

In Fig. 4 this result is presented in a so-called SchultzFlory product distribution, typically used in FischerTropsch catalysis studies. Chain growth probability is expressed in relation to weight fractions of products as described in Eq. 1 [17],

$$
w_{\mathrm{n}}=\left(\ln ^{2} \alpha\right) \cdot n \alpha^{\mathrm{n}}
$$

in which $n$ is the carbon number [-], $w_{n}$ is the weight fraction [-], and $a$ the chain growth probability. The chain growth probability, $a$, is estimated to be 0.27 from the slope of the trend line shown in Fig. 4. Notably, paraffins show an almost perfect linear correlation, while in the case of olefins $\mathrm{C}_{2} \mathrm{H}_{4}$ is an exception. This suggests that $\mathrm{C}_{2} \mathrm{H}_{4}$ is produced via another reaction path than chain propagation, resulting in a deviation from the Schultz-Flory distribution. This is in agreement with a previous study using $\mathrm{Cu}$ electrodes with $\mathrm{CO}$ and $\mathrm{CO}_{2}$ as reactants, in which the reaction paths for $\mathrm{C}_{2} \mathrm{H}_{4}$ and $\mathrm{CH}_{4}$ were suggested to be different [19].

To further tune the product selectivity of the Eurofysica $\mathrm{Cu}$ foil (without electro-polishing), we have studied the effect of the applied current density on the product distribution. Galvanostatic experiments were conducted at different current densities: 1,5 and $8 \mathrm{~mA} / \mathrm{cm}^{2}$. The development of product quantities as a function of time at $5 \mathrm{~mA} /$ $\mathrm{cm}^{2}$ is shown in Fig. 5a and the product distribution after $720 \mathrm{C}$ had passed through the cell in Fig. 5b. Since the
Fig. 3 (a) A gas chromatogram of $\mathrm{CO}_{2}$ reduction on $99.9+\% \mathrm{Cu}$ (Eurofysica) without electropolishing. Galvanostatic operation at $2 \mathrm{~mA} / \mathrm{cm}^{2}(-1.65 \mathrm{~V}$ vs. $\mathrm{Ag} / \mathrm{AgCl})$; after passing 720 $\mathrm{C}$ through the cell. (b) Corresponding relative weight fractions of each of the products formed

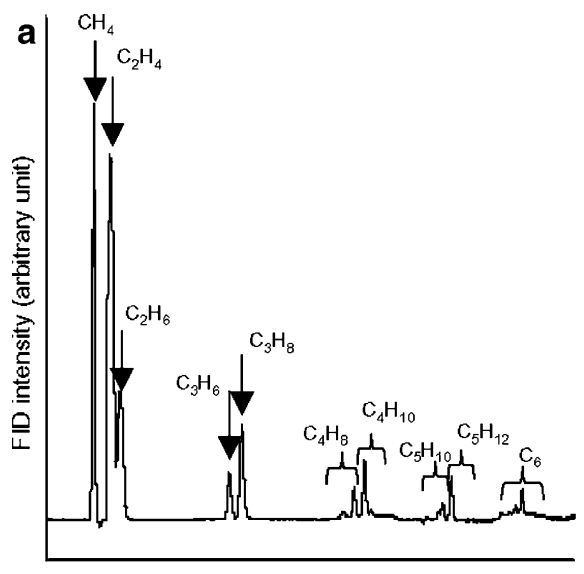

Retention time (arbitrary unit)

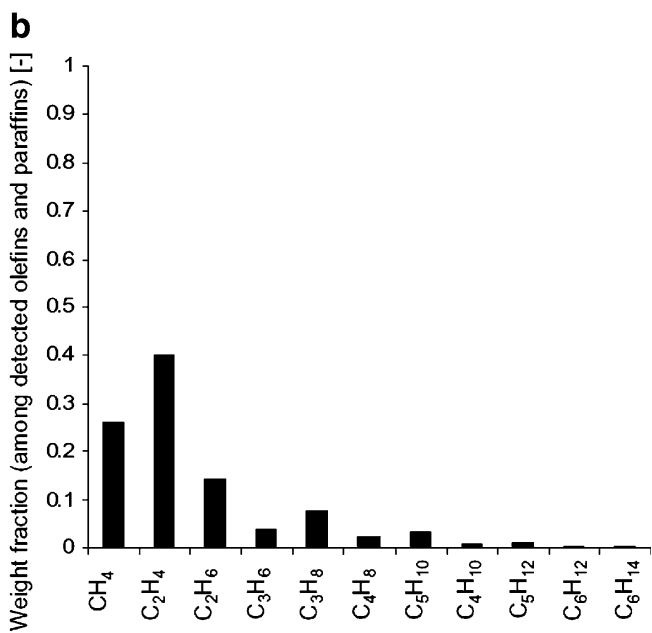




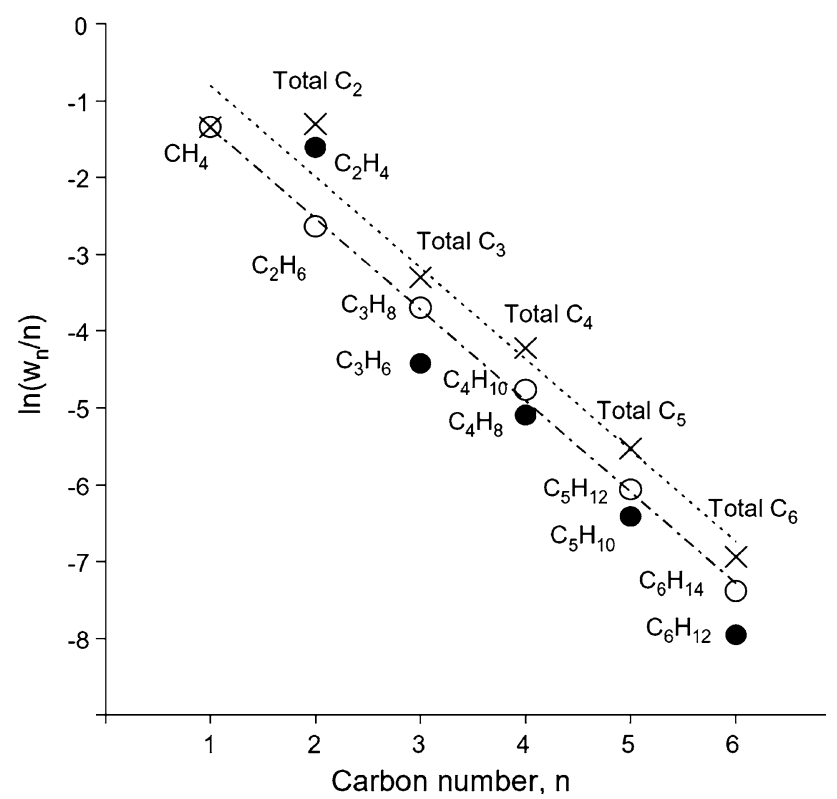

Fig. 4 Schultz-Flory product distribution of the electrolysis products formed over the $99.9+\% \mathrm{Cu}$ (Eurofysica). Galvanostatic operation at $2 \mathrm{~mA} / \mathrm{cm}^{2}(-1.65 \mathrm{~V}$ vs. $\mathrm{Ag} / \mathrm{AgCl})$; after passing $720 \mathrm{C}$ through the cell. $\mathrm{n}$ : Carbon number $[-] ; \mathrm{w}_{\mathrm{n}}$ : Weight fraction [-]; ०: Paraffins; $\bullet$ : Olefins; X: Total $\mathrm{C}_{n}$; - - - -: Trend line for total $\mathrm{C}_{n} ; \cdot \cdot-\cdot-$ : Trend line only for paraffins (Trend lines are obtained by linear regression)

experiment was conducted in a batch system, the molar concentration increases, rather linearly, as a function of time (the corresponding current passed through the cell is shown at the top axis of Fig. 5a). Deactivation of the electrode, reported in many other studies, is not apparent yet in the first hours of the reaction investigated in the present study. The product selectivity is also rather constant (straight lines in product growth for each of the species); not surprising in view of the low conversion of $\mathrm{CO}_{2}$ in the batch reactor. An induction time is apparent before the products appear. This induction period was also observed in various other experiments in our laboratory. Since the gas phase above the electrolyte was sampled for the analysis, it is likely that the induction period is the result of some solubility of the product gases in the electrolyte. Although these are low, the amount of products formed is as well ( $\mu$ mole range). Increasing the current density from $2 \mathrm{~mA} / \mathrm{cm}^{2}$ to $5 \mathrm{~mA} / \mathrm{cm}^{2}$ changed the relative product distribution (compare Figs. $3 \mathrm{~b}$ and $5 \mathrm{~b}$ ), favoring the formation of $\mathrm{C}_{2}$ products, especially ethylene, to the expense of long chain products.

The concentrations of the predominant products (categorized as $\mathrm{C}_{1}, \mathrm{C}_{2}, \mathrm{C}_{3}$ and $\mathrm{C}_{4}$ hydrocarbons) as a function of current density are shown in Fig. 6. Clearly $\mathrm{C}_{2}$ hydrocarbons maximize at a current density of approximately $5 \mathrm{~mA} /$ $\mathrm{cm}^{2}$ (corresponding to a voltage of $-1.9 \mathrm{~V}$ vs. $\mathrm{Ag} / \mathrm{AgCl}$ ), while the amount of $\mathrm{CH}_{4}$ produced is increased at a current density of $8 \mathrm{~mA} / \mathrm{cm}^{2}$. Chain growth probabilities were also calculated for each current density, compared at equal levels of electric charge passed through the cell, i.e. 720 Coulomb. The data are listed in Table 1, together with the corresponding Faradaic efficiencies. Faradaic efficiencies of total hydrocarbon production reach $\sim 7 \%$, when electrolysis was carried out at $-1.90 \mathrm{~V}$ vs. SHE $(5 \mathrm{~mA} /$ $\mathrm{cm}^{2}$ ). Hydrogen was the co-product accounting for the remaining electron consumption (see Fig. 2). In agreement with the trend shown in Fig. 6, the chain growth probability is affected by changing the applied potential. Two phenomena are important to explain the changing chain growth probability and the trend of Fig. 6. Firstly, Hewitt reported that the surface coverage of adsorbed hydrogen increases as a function of increasing negative potential [20]. Second, it has been reported that the $\mathrm{CO}$ surface coverage, which is proposed to be a key intermediate in $\mathrm{CO}_{2}$ reduction, is also a function of the applied potential [21]. The coverage of $\mathrm{CO}$ was reported to maximize at $-1.2 \mathrm{~V}$ vs. SHE, while it decreases at more negative potentials $[21,22]$. As a consequence of these observations, the surface $[\mathrm{H}] /[\mathrm{CO}$ or $\mathrm{CO}_{2}$-derived intermediate] ratio is expected to increase at more negative potential. This is equivalent to varying the $\mathrm{H}_{2} / \mathrm{CO}$ ratio in the "normal" catalytic Fischer-Tropsch reaction at elevated temperatures and pressures over Co or
Fig. 5 (a) Product development over the $99.9+\% \mathrm{Cu}$ (Eurofysica) electrode as a function of reaction time at a current density of $5 \mathrm{~mA} / \mathrm{cm}^{2}$. Molar production of $\mathrm{C}_{1}$ and $\mathrm{C}_{2}$ ( $\mu \mathrm{mol})$, left axis. Molar production of $\mathrm{C}_{3}$ and $\mathrm{C}_{4}(\mu \mathrm{mol})$, right axis. Top axis: Total Electric charge passed through the cell (C). (b) Relative weight fractions of each of the products formed after passing $720 \mathrm{C}$ through the cell
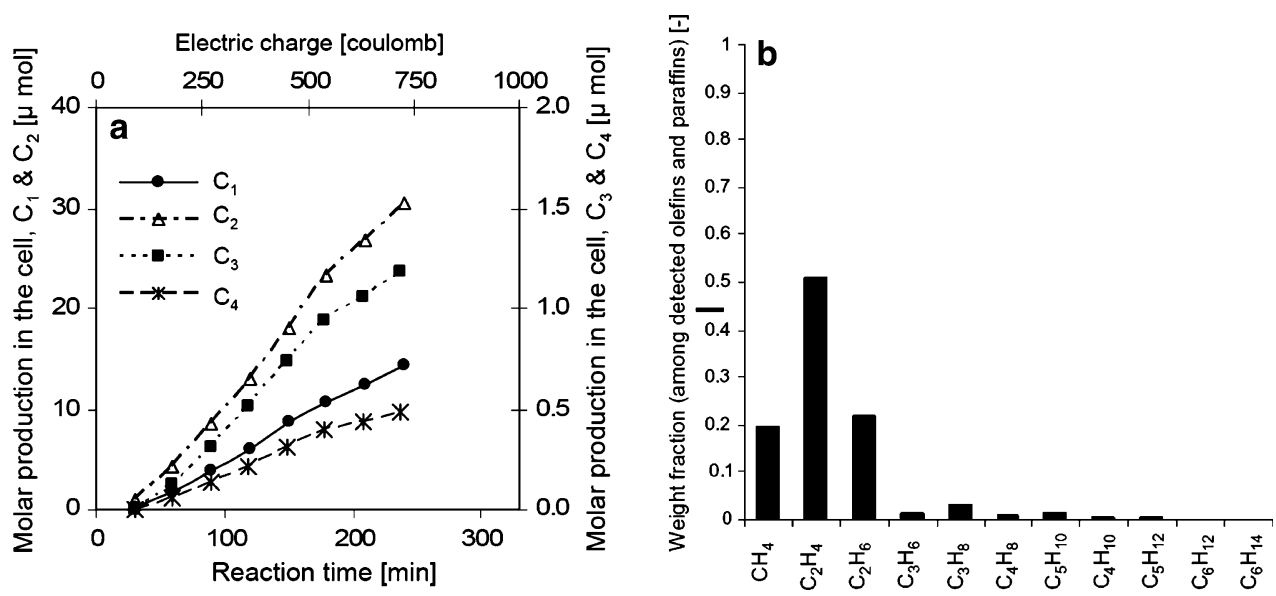


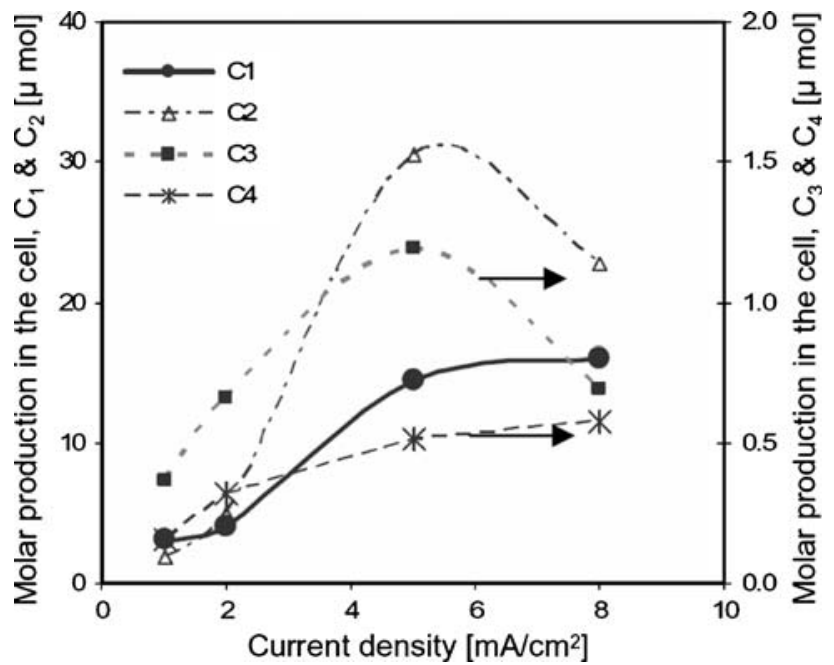

Fig. 6 Product development $(\mu \mathrm{mol})$ after passing $720 \mathrm{C}$ through the cell over the $99.9+\% \mathrm{Cu}$ (Eurofysica) electrode as a function of current density

Fe catalysts. Increasing the $\mathrm{H}_{2} / \mathrm{CO}$ ratio results in increasing total activity, and decreasing chain length $[17,23]$. This trend is in agreement with the increasing total activity and decreasing chain growth probability at more negative electric potential observed in this electrocatalytic study. This also explains the increase in relative

Table 1 Chain growth probability as a function of the applied current/electric potential over Eurofysica $\mathrm{Cu} 99.9+\%$ electrodes, without electropolishing

\begin{tabular}{llll}
\hline $\begin{array}{l}\text { Current } \\
\text { density } \\
{\left[\mathrm{mA} / \mathrm{cm}^{2}\right]}\end{array}$ & $\begin{array}{l}\text { Electric } \\
\text { potential } \\
{[\mathrm{V} \text { vs. Ag/AgCl] }}\end{array}$ & $\begin{array}{l}\text { Chain growth } \\
\text { probability, } \alpha^{\mathrm{a}} \\
{[-]}\end{array}$ & $\begin{array}{l}\text { Faradaic } \\
\text { efficiency [\%] }\end{array}$ \\
\hline 1 & -1.60 & 0.31 & 2.0 \\
5 & -1.90 & 0.24 & 7.1 \\
8 & 2.00 & 0.23 & 6.1
\end{tabular}

a The chain growth probability, $\alpha$, is estimated from the slope of the trend line drawn for total paraffin and olefin production (up to $\mathrm{C}_{4}$ ) amount of methane formed at $8 \mathrm{~mA} / \mathrm{cm}^{2}$ vs $5 \mathrm{~mA} / \mathrm{cm}^{2}$ (Fig. 6).

The Eurofysica $\mathrm{Cu}$ foil $99.9+\%$ was also examined after electropolishing. The product distribution changed drastically. Mainly $\mathrm{CH}_{4}$ and $\mathrm{C}_{2} \mathrm{H}_{4}$ were formed, with just traces of $\mathrm{C}_{2} \mathrm{H}_{6}$ and higher hydrocarbons, as shown in terms of relative weight fractions in Fig. 7a. For this electrode, contrary to what was observed for unpolished electrodes in Fig. 5, the selectivity changes as a function of time, favoring ethane and propane over ethylene (Fig. 7b). Apparently the morphology and/or chemical composition of the electrode surface is changing in the course of the reaction. The most likely change is the formation of oxides, as we will further discuss later.

When the Alfa Aesar high purity foil (99.9999\%) was used, with or without electropolishing in concentrated $\mathrm{H}_{3} \mathrm{PO}_{4}, \mathrm{CH}_{4}$ and $\mathrm{C}_{2} \mathrm{H}_{4}$ were the only products formed, in agreement with the literature $[7,10]$. Selectivity changes as observed for the polished Eurofysica $\mathrm{Cu}$ foil were absent, and $\mathrm{C}_{3}^{+}$products were never observed. For reasons of brevity, the corresponding curves are not shown. It should be mentioned that applying other transition metal electrodes, besides in the special electrolysis cell configuration of Centi et al. [6], the formation of higher hydrocarbons $\left(\mathrm{C}_{3}^{+}\right)$was only reported at high pressure [24, 25] with efficiencies being extremely low, typically one order of magnitude lower than the hydrocarbon amounts obtained with $\mathrm{Cu}$-electrodes.

The question arises, what is the "magic" ingredient that makes the Eurofysica $\mathrm{Cu}$ foil 'as is' so uniquely effective. Three explanations can be proposed: (i) the presence of contaminants which are removed by the electropolishing procedure, (ii) a unique surface morphology that is strongly affected by electropolishing, and (iii) the presence of surface oxides, which are removed by electropolishing. To verify the first explanation, elemental analysis of the Alfa Aesar and Eurofysica $\mathrm{Cu}$ electrodes was conducted by $\mathrm{X}$-ray Fluorescence Analysis (XRF). From the XRF results,
Fig. 7 Weight fractions among detected paraffins and olefins of galvanostatic electrocatalytic $\mathrm{CO}_{2}$ reduction at $2 \mathrm{~mA} / \mathrm{cm}^{2}$ (corresponding to $-1.65 \mathrm{~V}$ vs. $\mathrm{Ag} / \mathrm{AgCl}$ ) over Eurofysica with electropolishing. (a) Product distribution after $360 \mathrm{~min}$ (b) after $1,160 \mathrm{~min}$
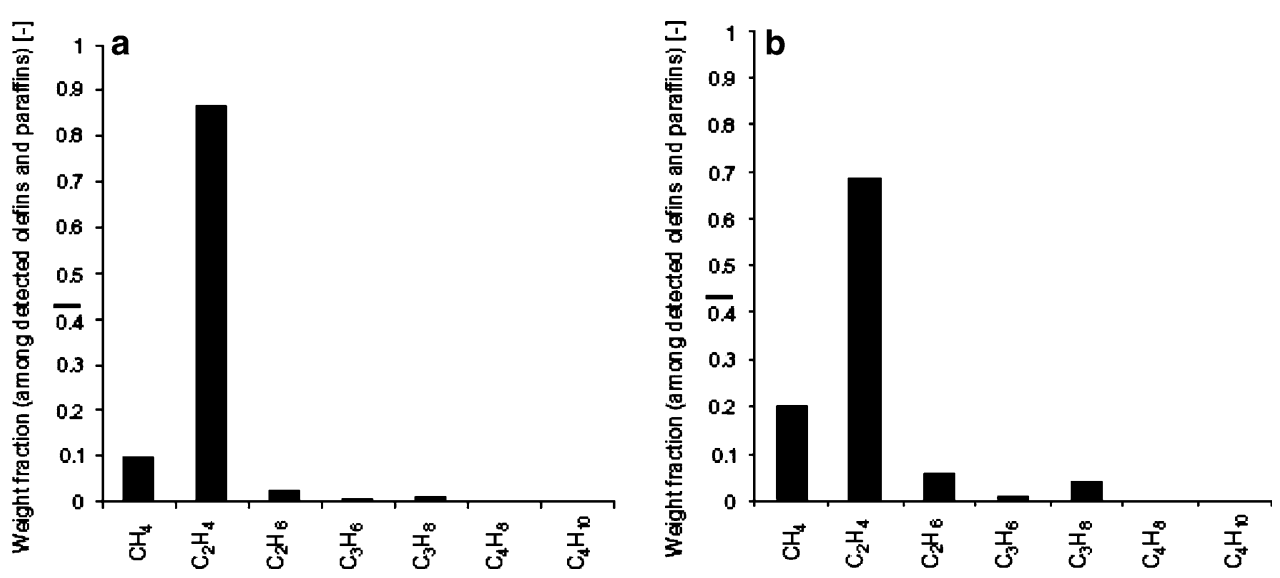
Table 2 Electrocatalytic activities, relative intensities of crystal planes, diffraction maximum and average diameter of the crystallite: Alfa Aesar $\mathrm{Cu}$ 99.9999\% and Eurofysica $\mathrm{Cu} 99.9+\%$, both with and without electropolishing

\begin{tabular}{|c|c|c|c|c|c|c|c|c|c|}
\hline \multirow[t]{2}{*}{ Electrode } & \multirow[t]{2}{*}{ Electropolishing } & \multirow{2}{*}{$\begin{array}{l}\text { Products from } \\
\text { electrocatalytic } \mathrm{CO}_{2} \\
\text { reduction }^{\mathrm{a}}\end{array}$} & \multicolumn{5}{|c|}{ 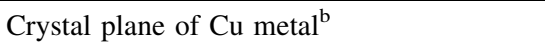 } & \multirow{2}{*}{$\begin{array}{l}\text { X-ray } \\
\text { Diffraction } \\
\text { maximum }[-]\end{array}$} & \multirow{2}{*}{$\begin{array}{l}\text { Crystallite } \\
\text { size }[\mathrm{nm}]^{\mathrm{c}}\end{array}$} \\
\hline & & & $(111)$ & $(200)$ & $(220)$ & $(311)$ & $(222)$ & & \\
\hline $\mathrm{Cu} 99.9+\%$ & No & Fischer-Tropsch & 100 & 64.1 & 56.1 & 29.7 & 3.7 & 9204 & 54 \\
\hline $\mathrm{Cu} 99.9+\%$ & Yes & $\mathrm{CH}_{4}, \mathbf{C}_{2} \mathbf{H}_{4}$, trace $\mathrm{C}_{2} \mathrm{H}_{6}$ & 100 & 56.6 & 83.8 & 36.5 & 3.4 & 9433 & 61 \\
\hline $\mathrm{Cu} 99.9999 \%$ & No & $\mathrm{CH}_{4}, \mathbf{C}_{2} \mathbf{H}_{4}$ & 2.3 & 100 & 0.2 & 0.2 & 0.1 & 276138 & 94 \\
\hline $\mathrm{Cu} 99.9999 \%$ & Yes & $\mathrm{CH}_{4}, \mathbf{C}_{2} \mathbf{H}_{4}$ & 2.2 & 100 & 0.2 & 0.2 & 0.1 & 295423 & 103 \\
\hline
\end{tabular}

${ }^{a}$ Major products are bold

b Values are normalized intensities-based on the most intense peak (bold)

${ }^{\mathrm{c}}$ Estimated applying the Scherrer equation

significant differences in the elemental composition between the Eurofysica and the Alfa Aesar electrodes were absent. Furthermore, compositional changes of the Eurofysica $\mathrm{Cu}$ electrode before and after polishing could not be established.

To verify the second explanation, the surface exposed index planes of the two types of electrodes were determined with X-ray diffraction (XRD). The XRD patterns reveal that Eurofysica $\mathrm{Cu}$ is rather polycrystalline with several crystal indices exposed, i.e. $\mathrm{Cu}(111),(200)$, (220) and (311), while Alfa Aesar Cu mainly consists of $\mathrm{Cu}(200)$ with a slight contribution of $\mathrm{Cu}(111)$, as indicated in Table 2. Although product distributions have been reported to be a function of the exposed crystal plane of Cu-electrodes [9], it is important to note that after electropolishing the X-Ray diffraction pattern of the electrode only shows minor changes, which makes a unique surface morphology being present before electropolishing not very likely.

This leaves the explanation for the remarkable behavior of the Eurofysica electrode to the presence of surface oxides. The polycrystallinity of Eurofysica may facilitate the formation of surface oxide complexes during ambient storage. The pure Alfa Aesar $\mathrm{Cu}$ electrodes are single crystallinelike, and, as a consequence, relatively insensitive to oxidation. This explanation is strongly supported by the changing selectivity of the Eurofysica electrode after electropolishing as a function of time. Initially the Eurofysica electrode shows 'normal' behavior (comparable to the pure 99.9999\% $\mathrm{Cu}$ plate), since the electropolishing procedure has removed the surface oxides. In the course of the experiment the electrode is (partially) oxidized in situ as a result of $\mathrm{CO}_{2}$ decomposition, leading to the observed selectivity changes towards Fischer-Tropsch like products. This oxidation, and accompanying selectivity changes are not observed for the Alpha Aesar electrode, presumably because of a higher stability against in situ oxidation as a result of the absence of surface reactive planes. Based on the present experimental data it is not possible to identify the active sites, and the oxidation state of the $\mathrm{Cu}$. The effect of the generation of oxidized active sites on copper electrodes on the product distribution in $\mathrm{CO}_{2}$ reduction has among others previously been investigated by Hori et al. [14] and Momose et al. [26]. Hori and coworkers deliberately oxidized copper electrodes at elevated temperatures in air. It was observed that after severe oxidation, ethane becomes a product of the reaction, whereas methane production decreases. This suggests that indeed surface oxygen would induce ethane formation, the product indicative for chain propagation reactions. Momose states that oxygen present at the electrode surface can lead to an enhanced adsorption of $\mathrm{CO}_{2}$. In analogy to FischerTropsch catalysis, it is thus likely that besides the applied potential, the surface $[\mathrm{H}] /\left[\mathrm{CO}\right.$ or $\mathrm{CO}_{2}$-derived intermediate $]$ ratio is decreased as a function of (initial) "oxygen" coverage of the $\mathrm{Cu}$-electrode surface, favoring long chain hydrocarbons.

To further substantiate the role of the oxidation state we have decided to initiate a new study-based on well defined copper electrodes modified in a controlled fashion either by oxidation or by in situ modification as a result of reaction in $\mathrm{CO}_{2}$. Electron microscopy (SEM), XPS, and surface enhanced Raman analyses will be performed to identify morphological changes and changes in the surface oxidation state.

\section{Conclusions}

In summary, the Eurofysica $\mathrm{Cu}$ foil, when not electropolished, converts $\mathrm{CO}_{2}$ into hydrocarbons with a previously never reported Fischer-Tropsch like product distribution. Paraffins and olefins up to $\mathrm{C}_{6}$ were observed. Chain growth probabilities are tunable by altering the applied potential. When the same electrode material was pre-treated by electro-polishing it behaved like a pure $\mathrm{Cu}$ electrode: mainly methane and ethene were observed. It is suggested that the oxygen coverage of the electrodes is a function of the surface crystallinity. Surface oxygen is proposed to be an important factor in controlling the selectivity in the $\mathrm{CO}_{2}$ activation. 
Acknowledgement Dr. Masahiro Furuya at Central Research Institute of Electric Power Industry (CRIEPI) of Japan, is greatly acknowledged for discussions and for providing the potentiostat. SENECU, the sustainable energy program of the TU Delft, is acknowledged for financial support.

Open Access This article is distributed under the terms of the Creative Commons Attribution Noncommercial License which permits any noncommercial use, distribution, and reproduction in any medium, provided the original author(s) and source are credited.

\section{References}

1. Tzimas E, Catello E, Peteves S (2007) Int J Hydrogen Energy 32:1369

2. Maeda K, Domen K (2007) J Phys Chem C 111:7851

3. Maeda K, Teramura K, Lu D, Saito N, Inuoe Y, Domen K (2006) Angew Chemie 45:7806

4. Anpo M, Yamashita H, Ichihashi Y, Fujii Y, Honda M (1997) J Phys Chem B 101:2632-2636

5. Electrochemical and Electrocatalytic Reactions of Carbon Dioxide (1993) Elsevier Science Publishers B.V., Amsterdam, The Netherlands

6. Centi G, Perathoner S, Wine G, Gangeri M (2007) Green Chemistry 9:671

7. Jitaru M, Lowy DA, Toma M, Toma BC, Oniciu L (1997) J Appl Electrochem 27:875

8. Chaplin RPS, Wragg AA (2003) J Appl Electrochem 33:11071123

9. Gattrell M, Gupta N, Co A (2006) J Electroanal Chem 594:1
10. Hori Y, Wakebe H, Tsukamoto T, Koga O (1994) Electrochim Acta 39:1833

11. Hori Y, Kikuchi K, Murata A, Suzuki S (1986) Chem Letters 897-898

12. Hori Y, Murata A, Takahashi R (1989) J Chem Soc-Faraday Trans 85:2309

13. Schwartz M, Vercauteren ME, Sammells AF (1994) J Electrochem Soc 141:3119

14. Koga O, Nakama K, Murata A, Hori Y (1989) Denki Kagaku 57:1137

15. Hori Y, Konishi H, Futamura T, Murata A, Koga O, Sakurai H, Oguma K (2005) Electrochim Acta 50:5354

16. Hori Y, Takahashi I, Koga O, Hoshi N (2003) J Mol Catal A-Chem 199:39

17. Van der Laan GP, Beenackers AACM (1999) Catal Rev-Sci Eng 41:255

18. Smith BD, Irish DE, Kedzierzawski P, Augustynski J (1997) J Electrochem Soc 144:4288

19. Hori Y, Takahashi R, Yoshinami Y, Murata A (1997) J Phys Chem B 101:7075

20. Hewitt TD, Roy D (1991) Chem Phys Lett 181:407

21. Gupta N, Gattrell M, MacDougall B (2006) J Appl Electrochem 36:161

22. Kudo A, Nakagawa S, Tsuneto A, Sakata T (1993) J Electrochem Soc 140:1541

23. de Deugd RM, Kapteijn F, Moulijn JA (2003) Catal Today 79:495

24. Ougitani Y, Aizawa T, Sonoyama N, Sakata T (2001) Bull Chem Soc Japan 74:2119

25. Azuma M, Hashimoto K, Hiramoto M, Watanabe M, Sakata T (1990) J Electrochem Soc 137:1772

26. Momose Y, Sato K, Ohno O (2002) Surf Interface Anal 34:615 